\title{
Mi köze van a tudásnak és az információnak a társadalomhoz?
}

Nem egy olyan fogalom megnevezésére használunk nyelvünkben szavakat, kifejezéseket, amelyek definícióját még soha senki nem adta meg. Aztán utólag sokszor mégis készülnek definíciók, egyfajta módon regisztrálva és visszaigazolva a használatot: ezekből állnak az értelmező szótárak. Szavaink, kifejezéseink egy része azonban soha nem kerül be az ilyen szótárakba, részben mert szakszavak és nem a napi élet részét alkotják, részben pedig azért, mert még mielőtt bekerülhetnének, kikopnak a használatból. Vannak azonban kifejezések, melyek egy adott időszakban definiálatlanul, de egyre gyakrabban fordulnak elő mind a napi sajtóban, mind a szaksajtóban. Ilyenek a saját korunkat - részben érthető, részben soha nem pontosított módon - információs társadalomnak, tudástársadalomnak és tudás-alapú társadalomnak nevező írások. Definiálatlan fogalmakkal a nyelvészeti elemzés ugyanúgy nem tud semmit sem kezdeni, mint a hétköznapi nyelvhasználó: ehhez sorakoztat fel néhány nyelvészeti érvet az írás.

Kulcsszavak: információs társadalom, tudástársadalom, nyelvi elemzés, jelentés

\section{Szerzői információ:}

\section{Prószéky Gábor}

Programtervezó matematikus, nyelvész, a MorphoLogic vállalat alapítója és ügyvezetố igazgatója, az MTA doktora. Elsősorban számítógépes nyelvészeti kutatásokat folytat. Számos nemzetközi tudományos társaság és magyar akadémiai bizottság tagja, valamint több hazai és nemzetközi tudományos folyóirat tanácsadó testületi, illetve szerkesztóbizottsági tagja. Kutatási eredményei elôsegítették különféle szóalaktani elemzô- és generáló-, lemmatizáló-, helyesírás-ellenôrző és elválasztóprogramok, egy- és többnyelvứ szótárprogramok, valamint nyelvtani ellenôrzốs és mondatelemző rendszerek kidolgozását, amelyek több ízben nemzetközi elismerést és díjakat érdemeltek ki. Itthon Kalmár László-díjjal és Széchenyi-díjjal tüntették ki. Az Informatikai Vállalkozások Szövetsége 2002-ben „az év informatikai menedzserének” választotta.

E-mail: proszeky@morphologic.hu

Így hivatkozzon erre a cikkre:

Prószéky Gábor. „Mi köze van a tudásnak és az információnak a társadalomhoz?”. Információs Társadalom VI, 1. szám (2006): 56-59.

$=$ https://dx.doi.org/10.22503/inftars.VI.2006.1.7 $\rightleftharpoons$

A folyóiratban közölt müvek

a Creative Commons Nevezd meg! - Ne add el! - Így add tovább! 4.0 Nemzetközi Licenc feltételeinek megfelelöen használhatók. 
Prószéky Gábor

\section{Mi köze van a tudásnak és az információnak a társadalomhoz?}

Nem egy olyan fogalom megnevezésére használunk nyelvünkben szavakat, kifejezéseket, amelyeknek a definícióját még soha senki nem adta meg. Aztán utólag sokszor mégis készülnek definíciók, egyfajta módon regisztrálva és visszaigazolva a használatot: ezekból állnak az értelmezó szótárak. Szavaink, kifejezéseink egy része azonban soha nem kerül be az ilyen szótárakba, részben mert szakszavak és nem a napi élet részét alkotják, részben pedig azért, mert még mielốtt bekerülhetnének, kikopnak a használatból. Vannak azonban kifejezések, melyek egy adott időszakban definiálatlanul, de egyre gyakrabban fordulnak elố mind a napisajtóban, mind a szaksajtóban. Ilyenek a saját korunkat - részben érthetô, részben soha nem pontosított módon - információs társadalomnak, tudástársadalomnak és tudásalapú társadalomnak nevezó írások. Ez a három fogalom ráadásul többé-kevésbé egymás szinonimájaként is használatos.

A helyes kérdés ezekkel a kifejezésekkel kapcsolatban elsôsorban az, hogy használatuk jól fedi-e azt, amire gondolunk. Nyilván az sem lényegtelen, hogy van-e az általuk megnevezni kívánt fogalmaknak egzakt definíciójuk, de azért a legtöḅb fogalom esetében nem az értelmező szótárakhoz fordulunk, hogy mit is jelenthetnek, hanem nyelvi környezetük alapján magunk is képesek vagyunk jelentésüket kitalálni. Hogy mire gondolunk egy fốnévként használatos szó esetében, azt természetesen sokkal könnyebb egy rámutatással is elérhetô objektummal illusztrálni, mint absztrakciókkal. Ez így is van rendjén, ám az emberi nyelvek nagy részében bizony az absztrakt fogalmak is megnevezhetốk.

A jelentésról a nyelvészet azt mondja, hogy a jelek használati szabálya (Morris, 1947). A jelviszony megvalósításához öt tényezố szükséges: a beszélő, a hallgató, a jel, a jel tárgya és maga a jelentés. Ám ezek közül a beszéloo, a hallgató és a jelölt tárgy nem tartozik a nyelvhez. Az elsố kettő használja a jelrendszert, de egyik sem része ennek a rendszernek. A jeltárgyak, más szóval denotátumok sem a jelekkel, sem a jelentésekkel nem azonosak (Antal, 1978). A mi fenti kifejezéseink esetében az az igazi probléma, hogy ezeknek a nyelvi terminusoknak a denotátuma magunk elốtt sem tiszta. A tudástársadalom, a tudásalapú társadalom és az információs társadalom kifejezéseket elsôsorban nem a mindennapi életünkben megjelenő szükségszerüség hozta létre, hanem létrejöttük okát a politikai-gazdasági élet és a nyelvi divathullámok metszete táján kell keresnünk. Mint általában az ilyen természetú dolgok esetében, ezeknek a vizsgálata sem végezhetố el pusztán elméleti nyelvészeti síkon, hiszen itt - a fent említettek miatt - a szociológiának legalább akkora szerepe van a terminológia vizsgálatában, mint magának a nyelvészetnek.

Ezért először nézzünk meg egy-két, a vizsgált fogalmakkal kapcsolatos, de nem nyelvészeti indíttatású definíciót. Az Információs Társadalom Tárcaközi Bizottságának honlapján (http://www.itktb.hu/engine.aspx?page=infotars) azt olvashatjuk, hogy „az 
információs társadalom fogalmának kiterjedtsége miatt nincs egyszerú definíciója". Farkas János (Magyar Tudomány, 2003/4) viszont ad definíciót, miszerint az információs társadalom „a társadalmi szervezet sajátos formája, amelyben az információ termelése, fogalmazása, alkalmazása a termelékenység és a hatalom alapvetô forrásává válik". Tehát az információs társadalom egyfajta társadalmi szervezet lenne?

Az információs társadalommal - bármi legyen is az - az irodalom alapján azt mondhatjuk, hogy szinte bármit lehet csinálni, például lehet monitorozni is, hiszen Az Információs Társadalom helyzete Magyarorsaágon 2003 végén címú tanulmány (IHM, 2004) „a magyar információs társadalom monitoringvizsgálatáról” szól. Ebben olyasmi is olvasható, hogy „az információs társadalom térhódításának kulcsfontosságú területe az elektronikus kormányzás". Az információs társadalom ezek szerint olyan, hogy képes teret hódítani, és vannak kulcsfontosságú területei. Így viszont kevéssé valószínú, hogy egy társadalmi szervezeti formáról van szó - amint Farkas definíciójában olvastuk.

A félő az, hogy nemcsak ezeket, hanem gyakorlatilag bármi mást is lehetne állítani róla, sốt késóbb, egy esetleges információstársadalom-definícióhoz ezeket az állításokat szerencsétlen módon akár fel is lehetne használni. Némi körkörösség látszik itt, akárcsak az emberek intuitív nyelvismeretére is épító értelmezố szótárakban, ahol bizony nemegyszer találkozhatunk ezzel a problémával. Legyen erre példa épp a tudástársadalom kifejezés egyik felének tövét alkotó tud ige és a belóle alkotott főnév (Értelmező kéziszótár, 1408):

tud $t s$ (és $t n)$ ige [...] 4. Nagy hozzáértése, tudása van.

tudás $f n 1$. Az a tény, hogy valamit tudnak. [...]

Vannak tehát kérdéseink, sốt alapkérdéseink. Például: mi az, hogy tudás? Ki tud mit? Mi az, hogy információ? Talán az a dolog, ami ahhoz kell, hogy egy adott területet jobban megismerjek. Az Értelmezố kéziszótár tájékoztatásról, felvilágosításról, értesülésról és adatról beszél. Érdemes abban maradni, hogy ezek mind ahhoz kellenek, hogy egy adott területról pontosabb képünk legyen, ám itt, a mi információs társadalmunk esetében melyik ez a terület? Talán a társadalom fogalmát kell legkevésbé definiálni. Az Értelmező kéziszótár szerinti definíció két emberekkel kapcsolatos értelmezést hoz: az emberi együttélés viszonyainak egyfajta összességét, illetve az ilyen viszonyok közt élő emberek összességét. A tudással összekapcsolva viszont rengeteg mindent jelenthet a társadalom, hiszen a fônévi összetételek belsố szerkezete a két fốnév igen sokféle relációját takarhatja. Csak hogy egy példát hozzunk: gondoljunk a fa szónak a különböző szerepeire a favágó, a fatetü, a fatelep vagy a faház összetételekben. A favágóban a fát vágják, a fatetü a fában lakik, a fatelepen a fát tárolják, a faház esetében pedig fából készítenek valamit. A tudástársadalom esetében is fennállhatnak hasonló problémák, tehát azt kellene világosan látnunk, hogy mit csinál a tudás a társadalommal, vagy épp a társadalomban?

Érdemes átnézni, hogy milyen lehetséges jelentésviszonyban lehet egy összetételen belül két fốnév. Az összevetést Károly (1969) szóösszetétel-kategorizálásának nyomán megpróbáljuk szisztematikusan elvégezni, és egyben rákérdezünk arra is, hogy a tudástársadalom összetétel beletartozhat-e az adott típusba. Csillaggal jelöljük, ha semmiképpen sem értelmezhetô az adott viszony, kérdôjellel pedig, ha esetleg szóba jöhet az adott értelmezés, bár kissé eróltetettnek túnik. 


\begin{tabular}{|c|c|c|}
\hline $\begin{array}{c}\text { A két összetételi } \\
\text { tag viszonya }\end{array}$ & Példa & Tudástársadalom \\
\hline alany & sasmadár $\leftarrow$ a sas egyfajta madár & *a tudás egyfajta társadalom \\
\hline birtokos & focibajnok $\leftarrow$ a focinak a bajnoka & ?a tudásnak a társadalma \\
\hline hely & ürrepülés $\leftarrow a z$ ürben való repülés & *a tudásban való társadalom \\
\hline eszköz & kardvívás $\leftarrow$ karddal való vívás & *tudással való társadalom \\
\hline szolgál & menedékhely $\leftarrow$ menedékül szolgáló hely & *tudásként szolgáló társadalom \\
\hline vmire való & munkanap $\leftarrow$ munkára való nap & *tudásra való társadalom \\
\hline ered & kéményfüst $\leftarrow$ a kéményból eredő füst & ?a tudásból eredố társadalom \\
\hline visel & férfiruha $\leftarrow$ férfiak által viselt ruha & *a tudás által viselt társadalom \\
\hline vminek való & gyerekadag $\leftarrow$ gyerekeknek való adag & *tudásnak való társadalom \\
\hline múködik & benzinmotor $\leftarrow$ benzinnel múködố motor & ?tudással múködố társadalom \\
\hline borít & hómező $\leftarrow$ hóval borított mezö & *tudással borított társadalom \\
\hline használ & hóhérbárd $\leftarrow$ a hóhér által használt bárd & *a tudás által használt társadalom \\
\hline szerez & autótolvaj $\leftarrow$ autót szerzố tolvaj & *tudást szerző társadalom \\
\hline tartalmaz & meseköny $\leftarrow$ meséket tartalmazó könyv & *tudást tartalmazó társadalom \\
\hline lakik & bányászotthon $\leftarrow$ bányászok lakta otthon & *tudás lakta társadalom \\
\hline hely & falfestmény $\leftarrow$ falon levő festmény & *tudásban levố társadalom \\
\hline tartozik & asztalláb $\leftarrow$ az asztalhoz tartozó láb & ?a tudáshoz tartozó társadalom \\
\hline áll vmiból & villasor $\leftarrow$ villákból álló sor & *tudásból álló társadalom \\
\hline hasonló & tökfej $\leftarrow$ tökhöz hasonló fej & "tudáshoz hasonló társadalom \\
\hline tart & lóistálló « lovak tartására szolgáló istálló & *tudás tartására szolgáló társadalom \\
\hline beszerez & baromfipiac $\leftarrow$ baromfik beszerzésére való piac & *tudás beszerzésére való társadalom \\
\hline készít & fagylaltgép $\leftarrow$ fagylalt készítésére szolgáló gép & *tudás készítésére szolgáló társadalom \\
\hline anyag & kabátszövet $\leftarrow$ kabát anyagának való szövet & *tudás anyagának való társadalom \\
\hline visel & feikendő $\leftarrow$ fejen viselt kendő & *tudáson viselt társadalom \\
\hline használ & karácsonyfa $\leftarrow$ karácsonyra „használt” fa & *tudásra „, használt” társadalom \\
\hline anyag & vasrúd « vasból készült rúd & *tudásból készült társadalom \\
\hline használ -ként & múhelykocsi $\leftarrow$ múhelyként használt kocsi & *tudásként használt társadalom \\
\hline
\end{tabular}

Egyetlen értelmezés esetében sem tudtuk tehát jó szívvel azt mondani, hogy az adott viszony fennáll a tudás és a társadalom szavak között! Ennél tovább viszont nyelvészeti osztályozással nemigen juthatunk. Meg kell állapítanunk tehát, hogy a két szó közti viszony ugyanolyan definiálatlan, mint ahogy korábban, intuitíve gondoltuk: mindenki azt ért rajta, amit szeretne.

Még egy nyelvészeti közelítésre érdemes egy kis idốt szánni, és ez a jelzős fớnévi csoportok lehetséges értelmezéséról szól. Az információs társadalom ilyen jelzôs kifejezés. A fônév elôtti minőségjelzô megjelenése miatt az adott fớnév fogalmának terjedelme szúkebbé tud válni: kérdés, hogy a társadalom és az információs szavak denotátumai alkotta halmazok metszete az információs társadalom-e, amint a piros dolgok és a kalapok jeltárgyhalmazainak metszete a piros kalapok halmaza? Gondoljunk csak egy ettól eltéró esetre, az intenzionális melléknevek problémáira, amire jó példa lehet például a kiselefánt. Ez az állat ugyanis „objektíve” nem kicsi, a mérete csak az elefántokéhoz képest lesz kicsi, de hogy mekkora, az már nem egyértelmú. Ez esetben mindössze az biztos, hogy a kis elefánt egyfajta elefánt. Kérdés, hogy az információs társadalom is ilyen-e, azaz az információs kifejezés ugyanúgy nem jelenti azt, hogy a társadalom valóban ,információs", ahogy a kiselefánt sem kicsi? Mivel a piros kalapok esetében mind a piros dolgok, mind a 
kalapok denotátumaival, jeltárgyaival tisztában vagyunk, sốt az elefántok, és azokon belül akár a kiselefántok is viszonylag jól kezelhetók - bár ez utóbbiak kijelölése kissé bizonytalan lehet -, az ,információs”-ság jeltárgyairól igen kevéssé lehetünk biztosak. Magyarul: annak az eldöntése, hogy ez a lehetséges társadalmak fogalmának miféle megszorítása, nyelvészeti alapon nemigen lehet nyilatkozni.

Eljutottunk tehát odáig, amit az elején is sejtettünk: definiálatlan fogalmakkal a nyelvészeti elemzés ugyanúgy nem tud semmit sem kezdeni, mint a hétköznapi nyelvhasználó. Ködös kifejezéseink megmagyarázását tehát senki se a nyelvtudománytól várja.

\section{Irodalom}

Antal, L. (1978): A jelentés világa. Budapest: Magvetó.

Károly, S. (1969): A szóösszetételek és a velük kapcsolatos lexikai egységek (A fônévi összetételek). Általános Nyelvészeti Tanulmányok, VI, 271-358.

Morris, Ch. (1947): Foundation of the Theory of Signs. International Encyclopedia of Unified Science.

Chicago, Vol. 1. No. 2. 